\title{
The Nordic Model in a Global Company Situated in Norway. Challenging Institutional Orders?
}

\section{Hege Eggen Børve'}

Associate Professor, College of Nord-Trondelag, Levanger, Norway

1 Elin Kvande

Professor, Department of Sociology and Political Science, Norwegian University of Science and Technology (NTNU), Trondheim, Norway

\begin{abstract}
In this article, we explore the impact of internationalization as organizational processes where institutional actors meet in local contexts and negotiate the institutional order. The internationalization of working life implies that different traditions and practices meet and challenge each other.The focus is on how important elements of the Nordic micro model like cooperation between employees and employers and regulation of working hours are implemented in a global company situated in Norway.

In general, it seems that employees and employers cooperate in line with this tradition in the Nordic micro model. Norwegian manager's practices are described to be in accordance with Scandinavian management traditions, while managers from the United States appear to practice management consistent with the liberal working life model. The findings show a tension-filled clash between two different management practices, which indicates that the Nordic micro model in this field might be under pressure.

Manager's recommendation to the employees was not to become members of the trade union. The absence of trade unions in the organization implies that employees and employers are not cooperating on a collective level. This means that only parts of the regulatory arrangement related to participation and cooperation are implemented.

Findings concerning working time and the relation to the institutional order represented by the Norwegian Work Environment Act indicate a clear tension between different institutional traditions in the organization. The company does not respect the Norwegian in working time regulations. These regulations are seen as counterproductive for a company that competes in the international market. This devaluation of the regulations in the Nordic model implies that the institutional order represented in the Nordic micro model is challenged.
\end{abstract}

\section{KEY WORDS}

Globalized working life / Nordic micro model / Institutional order

\section{Introduction}

$\mathrm{n}$ this article, we focus on how the Nordic model functions in the context of increasing internationalization of work organizations. We will use the concept the Nordic micro model (Hernes 2008) in order to look into political processes on the organizational

\footnotetext{
${ }^{1}$ Hege Eggen Børve, College of Nord-Trondelag, Røstad, 7600 Levanger, Norway.

E-mail: hege.borve@hint.no
} 
level, which include the employees' informal and formal influence on how the company is organized and how this affects the daily work situation for the employees. The Norwegian and the Nordic work and welfare state regulations differ in some ways from the norms of international working life. International companies must, however, adjust to national and institutional regulations in order to achieve local legitimacy (Scott 2008). At the same time, they are also influenced by processes in global contexts (Freeman 2001) and of the social institutions in the countries, which have fostered them (Morgan 2001).

When national and external institutional contexts meet, tensions may arise that lead to changes in the way national institutions work. Increased internationalization could affect Norwegian working life regulations and lead to the development of new local practices (Børve 2010). In this article, we take as our point of departure a Norwegian technology company, which has become an international enterprise operating in four different continents. This company is part of what we refer to as knowledge work, which is defined as work with a great degree of problem solving and high level of qualifications that often requires non-standardized working conditions (Alvesson 1995, 2004). The research questions will therefore focus on how important elements of the Nordic micro model like cooperation between employees and employers and regulation of working hours are implemented in this Norwegian technology company. In addition we ask whether we can observe tensions between the national and external institutional contexts.

\section{The Nordic micro model}

The key role of the state in working life means that the Nordic countries, in contrast to other European countries, are considered to have a regulated workplace context with control systems that follow national laws and rights. The Nordic model encompasses institutional arrangements, which include employment regulations and welfare state services geared toward the inclusion of both male and female employees in working life. Though the Nordic countries have different histories, economics, and industrial structures (Schramm-Nielsen et al. 2004), their common cultural roots have resulted in them also having many similarities.

The characteristics of the Nordic model reflect these similarities, one of which is the emphasis on the cooperation model for employers and employees. This includes different ways of involving employees in decisions within the companies, through formal and informal participation. Formal participation is related to professional organization of the employees and cooperation between employee representatives and employer. This can be done by using employees as members of board of directors (Westenholz 2003). Informal participation is connected with employees' opportunities for influence in the daily work situation, as emphasized in the Working Environment Act $\$ 12$. This form of participation can be done through organizing autonomous work groups or using skilled employees as strategic company actors (Skorstad 2007). According to this way of thinking, the company is understood as a political system in which employees should have influence on how the company is organized and managed. This has been called the Nordic micro model (Hernes 2008) or micro democracy (Westenholz 1999). Researchers have labeled this type of emphasis on cooperation and representation as employees being "citizens of the companies" in order to underline the democratic aspect (Christensen and Westenholz 1999). 
An important feature of the model is the mutual recognition of rights and obligations. Employee's individual rights anchored in laws, agreements, and unions influence institutional conditions that limit manager's autonomy (Gooderham et al. 2006). Managers are expected to encourage participation and empowerment. This implies that the Nordic model includes a certain management model (Trygstad and Hagen 2007), socalled Scandinavian management, which is often seen as embracing democratic practices (Fleming and Törnquist 2003; Schramm-Nielsen et al. 2004). These are also important elements in the organization of work in knowledge organizations (Alvesson 2004; Alvesson and Kärreman 2004). Managing knowledge workers requires that managers themselves act as good team players as well as leaders. Knowledge workers require knowledge managers, not bosses. What type of management practices that are implemented in international companies, is important for whether the Nordic work model is maintained or not. The Norwegian bargaining system and its form of representative democracy rests on the idea of a strong correlation between cooperation and competitiveness.

The Work Environment Act specified workers' rights concerning working time. Working time regulations limit the length of working hours and the time one is available for the company. In accordance with the law, the ordinary working hours shall not exceed an average of 40 hours per week. Organizations are legally required to have an overview that shows how much each employee has worked. The combination of strong trade unions and regulated working conditions is thought to protect the workers (Olsen 2006). The collective arrangements in the Nordic model have also got a regulating and including effect for employees. On the macro level, we find that state, capital, and labor collaborate on the economic policy in these countries. This model is different from the liberal model of organizing (Esping-Andersen 1990, 1999) within capitalistic societies, which is characterized by low labor union membership and low participation from employees in decision making in companies. This liberal model can be found in countries like the United States, Great Britain, and Canada.

In sum, we can say that the Nordic micro model (Hernes 2008) is characterized by the following:

- Informal and formal participation by employees in decision making within companies

- Collective bargaining in companies and on the societal level

- High rate of unionization among employees

- Regulation of working time

In this article, we will concentrate on two elements of the Nordic micro model. First, we will analyze the cooperation between employees and employers. In order to do this, we explore the management practices and the attitudes toward unionization in the company. Second, we focus on the regulation of working time by exploring how the company is organized and the effect this has on working time.

\section{Internationalization and institutional perspectives}

We will apply institutional theory to examine how processes of internationalization influence practices that are part of the Nordic micro model. The perspective implies that institutions are perceived as central to understanding the interaction between organizations 
and the outside world. Institutions include regulative, normative, and cultural-cognitive elements, where each provides different basis of legitimacy (Scott 2008). Regulatory system emphasizes what the law sanctions as legitimate, normative has a moral basis for what is legitimate, while cognitive builds legitimacy on what actors share an understanding about what is appropriate and inappropriate.

Research from the United States on flexible work organizations shows how the formal working contract that regulates working time and other working rights is often replaced by moral values and norms that expect total commitment from employees (Blair-Loy 2003; Hochschild 1997). In these time cultures, the various family-friendly policies offered by companies are not used because the employees fear that they will be seen as "time deviants" who do not meet corporate time discipline expectations and that this will affect their opportunities and career advancement in the company (Epstein et al. 1999). This type of flexible and boundaryless time culture (Børve and Kvande 2007), which is seen in international working life, contrasts the working hour provisions regulated by the Norwegian Work Environment Act (Børve 2008). A possible implication of increased internationalization is that national institutional characteristics have less impact on how companies organize working time (Olsen 2006).

According to institutional theory, multinational firms are social constructions that are created within specific national institutional contexts, which shapes how they are internationalized (Morgan 2001). The national institutional context is thus regarded as critical for how organizations and practices are designed at the local level (see, e.g., Powell and DiMaggio 1991; Scott 2008). Norwegian research in this field has focused on studying a possible export of working traditions when companies are established abroad (see, for instance, Løken et al. 2008; Osmundsen 2005). There is also some research on the transfer of organizational practices of multinational companies with foreign owners and managers (see, for instance, Gooderham et al. 1999; Heiret 2003; Lervik 2005; Ringdal et al. 2005; Røvik 2007).

The main focus in several of these studies is on the managers as the organizations' internal translators (Røvik 2007). Some of these studies show that Norwegian firms import international models and practices and implement them within the Norwegian working traditions, while foreign-owned firms and multinational companies apply a model that increasingly violates Norwegian working traditions. We lack research on how internationalization processes affect the practices of labor regulations and welfare programs in international professional organizations located in Norway with Norwegian owners. The article is therefore a contribution to research in this field and our focus is on the experiences and understandings of the employees in the company. Internationalization of working life might imply that different traditions and practices meet and challenge each other. By applying institutional theory, we will analyze the impact of internalization as organizational processes where institutional actors meet in local contexts and negotiate the institutional order of organizing in concrete practices. This way of analyzing is inspired by Westenholz (2011) in her work on different institutional orders of organizing in Scandinavia and other regions. The key concept is institutional work, which refers to the practices that actors embedded in different institutional orders carry out. This institutional work is understood as the actions of individuals and organizations aiming at maintaining, changing, and challenging institutional orders (Lawrence and Suddaby 2006). 
Our main question in this article is therefore, How is the Nordic micro model practiced by employees and employers in a multinational company situated in Norway? First, we focus on how the tradition of cooperation between employees and employers is implemented by exploring management practices. Second, we analyze how working time is organized and regulated in this company. Through these points of entry we will be able to explore whether there are observable institutional tensions and challenges in this globalized company.

\section{Research design and data}

This article is based on a case study carried out in a company that is part of a global working life sector. The purpose of the study was to gain insight into the importance of global cooperation for Norwegian businesses in regard to issues such as work organizations, management practices, working conditions, and time culture.

The research design is explorative and based on a qualitative approach. According to Yin (1989), case studies are suitable when the research questions are explorative. The case study company was selected according to the following three criteria: knowledge organization with global presence, location in Norway, and knowledge workers with children. The case study subject is an IT organization that produces technological solutions based on scientific knowledge. The company has roots in technology research in Norway. The sales and support offices and the human resources department are located in 15 countries in four continents. Ninety per cent of the company turnover takes places outside the Nordic countries. Norway is the prime site for recruiting engineers to the organization, which is the main argument for continuing product development of technology solutions in Norway. This global enterprise operates in four continents with its main base in Norway. The working language is English.

The analyses and findings are based on primary data, a case study carried out in a company that is part of a global working life sector. The data consist of indepth interviews with 10 employees. The employees are graduate engineers and are educated in Norway and/or abroad. All informants are Norwegian nationals with work experience from other international companies in Norway and/or abroad. At the time of the interviews, the company had nearly 500 employees, of which 190 of them worked in Norway. The organization has a relatively young staff; the majority being between 27 and 35 years of age. The gender distribution is much skewed with 90 per cent men.

We used an interview guide to make sure that all the informants got questions about the same topics. Each interview took about one and a half hour. The interviews were all taped and later transcribed. The data were in the first phase coded thematically, inspired by so-called open coding (Strauss and Corbin 1990). Then we focused on similarities and differences within the themes. The interviews revealed that the workers were a relatively homogeneous group, meaning that there was little variation between employee responses and discussions during the interviews. In the empirical part of the article, we explore how the tradition of cooperation between employees and employers is implemented by exploring management practices and how working time is organized and regulated in this company. 


\section{Cooperation between employees and employers}

Different national contexts provide different conditions for management practices and institutional environment elements as workers' individual rights and trade unions influence on managers' practices. In this section we focus on how the tradition of cooperation between employees and employers in the Nordic micro model is implemented, by exploring management practices.

The company is organized into three levels: a top management consisting of a management team, a middle management level with six department managers, and then the rest of the employees. The majority of the managers are ethnic Norwegian, while the minority are ethnic Americans. The employees point out that there are major differences between management practices. Tom, who has an American manager, says, "they (the Americans) represent a very different management style, which is very un-Norwegian." He elaborates on the differences:

"My American managers here are more hierarchical, the Americans are more like: I am your manager, you are the employee. You have to accept these differences. While many of the Norwegian managers are like: You know they are managers, but they don't have to say it. They are relaxed."

American managers are characterized as management according to hierarchical position and reference to their higher position, while other managers are less concerned about emphasizing their position as managers. Siri shares this opinion. She expresses her thoughts about US managers:

"The US leadership style is very authoritarian - if they say jump, you only ask how high. It was a bit unusual as I am accustomed to thinking for myself and not being flash ruled on many things that can be operated on here. The Norwegian managers, in a sense, respect the employees they listen, they are polite, they are calm and don't explode."

Hierarchy according to rank denotes the distance between the top and bottom levels. Those on the bottom level have the least influence on decisions. The higher one's level, the greater degree of influence one has. US managers are characterized as authoritarian and as managers who exercise control over employees who are below them in the hierarchy. The Norwegian managers were described as behaving more in line with Scandinavian management practices, which are based on a democratic relationship between the employee and the employer. The employee-employer relationship seems to be based on trust and a common understanding that the best results are achieved through cooperation.

Siri has also worked for other international companies and says it is difficult to have a manager who is controlling and gives orders:

"I have had conflicts with US managers and their management style. I am too old to be ordered around. It is about how one treats people. I couldn't handle it, to be talked to as if I was a newly graduated 20-year-old when I am capable of doing the job without interruption - an irrelevant interruption, sometimes it was too controlling. I take responsibility, no problem. One doesn't need slavery; one needs trust and good working conditions in order 
to be able to contribute. (...) He has a manager in the US who is tough. In a way it is hard for him and then he uses the same management style."

Use of control rests on the idea that workers must be managed, regardless of their competence level. This stands in contrast to the autonomous knowledge workers who can develop and use their knowledge creatively (Alvesson 2004; Drucker 1999). Siri's reaction can be read as one of disappointment. She expects to be treated with respect, as a result of her past experiences with managers from other organizations, her competence level, and as a result of the decentralized organization structure that symbolizes the responsibility and decision-making delegation. A precondition for cooperation between employers and employees is trust between the institutional actors. When direct control is used, it is understood as an expression of distrust for an employee who has been used to the Nordic micro model. This challenges the institutional order when it comes to cooperation between employees and employers.

We were told a story during the interviews about how US employees had experienced Norwegian managers' practices when they were placed in the US branch of the company. The story illustrates that some employees do not expect managers to exercise trust and respect.

"He [one of the top-managers] had been at the office [in the US] to talk with someone [employee] who had done something wrong, seriously wrong. The employee was terrified - the Norwegian manager was coming. The only thing he [the Norwegian manager] did was to put his hand on his shoulder and said: 'this will be solved, we are able to solve this'. The employee collapsed, because he expected to be fired or at least shouted at, but that is the US style."

Sigurd refers to a story a Norwegian manager had told him. The story illustrates a break between expectation and practices and substantiates an understanding of differences and contradictions between management practices. These represent negotiations that might contribute to challenge the institutional order when it comes to cooperation between employees and employers.

Several of the employees say that although they experienced some management practices as inappropriate, they felt it is important to show that they accept the different practices. This can be seen as an adaptation strategy in order to avoid conflict. Erle has, however, chosen a different strategy, which had led to a conflict between her and the manager. She is a temporary employee and is unsure about whether she wants to continue in the job because of the stress that is caused by constantly having to negotiate with her manager. She had told the manager that she did not fit into the organization. About the reaction she got from the management she says, "It seemed like they were a little distraught, because I think they wanted me to stay."

While some employees reacted negatively to the "soft" managerial practices, other employees reacted negatively toward managers' use of control. This illustrates that they have different understandings and expectations regarding management practices. The perception of appropriate and inappropriate management practices is institutionalized in various national contexts. The management elements that employees perceive as natural and in line with their expectations depend on location and national origin. Sivert illustrates this when he talks about Norwegian employees. He believes that the Norwegian and US workers have different expectation toward managers' practices: 
"We Norwegians are not hierarchically oriented in the same way. We are more independent and we even dare to make decisions. They are so polite that it's almost annoying; they are just another person in a hierarchy, while the Norwegians just blurt out what they mean about different topics."

Hierarchical orientation implies using power and control according to one's hierarchal position. The one who is on the lowest level is expected to behave according to their subordinated position. The distinction, which is brought up here, is on the one hand autonomy and use of decision-making skills, while on the other hand a type of politeness that is understood as a means of displaying hierarchical inferiority and subordination. Independence might be an aspect of a trustful relationship between employers and employees. A requirement for being an employee who is independent and makes decisions is a management practice where responsibility and decisions are delegated to employees. Jan, who comes from the United States, talks about the differences between employees:

"It seems to me that all Norwegians have the feeling that they are important enough to be heard; 'I am important'. You are not really important in the US. You are just a person, their threshold between employer and employee is higher."

Several of the employees say that in US working life, hierarchical position is crucial for one's power, authority, and importance. This type of understanding is not congruent with the employees' professional identity in the Nordic context. The description above fits well with local norms rooted in the Nordic institutional environment: to be heard is a prerequisite for influence and participation opportunities. These are rights that are reflected in both the employees' direct participation rights and indirect participation rights through collaboration. The consequence is that employees expect a form of equal treatment, regardless of hierarchical position.

Lucas, who is American, spoke about his first experience as an employee in Norway. His story supports that workers' participation rights are institutionalized as a framework for the institutional work that is carried out by the actors in working life.

"It was a bit problematic in the beginning, because I had respect for my managers .... I worked two years [in Norway] before I came to this company, and we had managers who were Norwegian. I had a very hard time because I had others in my group who were a bit cheeky really, like in a way, 'Oh my God how dare you say that?' It was very difficult at first to understand it, to go in and just like that, you can't really yell at a partner or say more about what you mean, it took me some time, but I'm starting to feel like I really am a good mixture now. So, I'm accustomed to hierarchy, but not that I'm afraid of managers."

Being an employee in Norwegian working life was, according to Lucas, a meeting of institutional practices that differed from his previous experience from the US workplace where a direct and informal communication with managers was unusual. The US workplace appears to be based on etiquette between employer and employees where hierarchical position plays a defining role for what an employee can or cannot say. Although Lucas still relates to US standards, he has internalized aspects of the local norms. Thus, 
there is a change and adaption taking place. Even though the Norwegian employees are affected by the company's international position and multinational staff, the employees agree that Nordic working life values and norms prevail in the company. Carl uses the concept empowerment in his description of which norms are typical for the company:

\begin{abstract}
"What we are good at is 'people empowerment'. That everybody is able to contribute. I think it is perfect. I think Norwegians have too little respect for authority .... I think Americans have too much respect for authority. (...) I think here it is adequate. The manager, she or he, should receive some respect. There is a reason why a person is a manager."
\end{abstract}

The concept empowerment is generally linked to delegation of authority to the individual employee. The prerequisite for empowerment is that employees are perceived as capable of being responsible and working independently. It also requires that the employees and employers trust each other. According to Carl, authority didn't come at the expense of respect for the managers as one manager had balanced accountability and authority. Jesper' explanation is that the work environment is characterized by the fact that people show concern for each other. These standards are more characteristic of a collective orientation rather than an individualistic orientation.

"You may have a social responsibility that is slightly larger than yourself and your family. You don't focus so much on how much money you can make yourself and you try to broaden your horizons a bit. I think we have exported some of what we might label as caring. Even if the environment at the office in the US is tougher, I think it is better than in a traditional US."

Per's explanation is the close cooperation between the company and its subsidiaries in the United States. He stresses that the Norwegian working life is very different from other countries:

"When it comes to the United States and Britain you may say they have removed the national context, they are universal, global. Their behaviour is learned and management is associated as global. The case of Norway is different; they have rules and a strong tradition considering justice. The equality perspective, reward and freedom are elements that can be said to be typical Norwegian."

Sivert argues that management practices were designed in collaboration with national regulatory schemes. While the development of global and universal management practices is explained as a consequence of the absence of regulatory systems, the stringent regulatory systems and values of equality are understood to limit the managerial autonomy (Gooderham et al. 2006). A common feature of the United States and the United Kingdom is the flexible and deregulated labor force (Esping-Andersen and Regini 2000). Management functions in the United States are often referred to as un-institutionalized and detached from its specific institutional context (Byrkjeflot 1997).

The cooperation model for employers and employees includes formal participation. The organization has very few employees who belong to a union. Some employers say that unions are only necessary if there is a discrepancy between employers and employees. They describe the cooperation between employees and employers as good. Other explanations were connected to the international customers and their dislike of unions. 
Per, who is one of the few who belongs to a union, explains, "They did not like that I had joined the union." He continues:

"There was a big customer from the US when this company had just started up. They [customers from the US] stressed that they did want anything to do with organized workers. Unions led to trouble. The managers then instructed us not to join any union.”

The customers' fear of unions must be understood as a result of them acting from the context of the United States where there is a long tradition of anti-unionization and conflicts between employers and employees (Trompenaars 1993). It is, however, interesting that the management of this Norwegian company chooses to comply with the request of a customer that has a very different tradition concerning unions. It can be read as an indication of how little willingness there is toward protecting Norwegian traditions concerning regulations. The difference between a boxing ring and a dance floor has been used to describe various models of cooperation between employees and employers (Huzzard et al. 2004). In the boxing ring, the relationship is characterized by conflicts of interest, and power is distributed in a zero-sum game. On the dance floor, the relationship is characterized by common interests and by a win-win situation. The better one of the part is to dance, the easier it is for others to follow, and the overall result is better. In the boxing ring, victory is the success criterion. On the dance floor it is the performance and the value of the cooperation itself, which is the success criterion. It is the manager who asks to dance. In the Norwegian context, the cooperation between employers and employees in general is consensus-oriented. Employers who practice in line with the Scandinavia management model are dancing with the employees. If you do not follow these practices, it implies a move toward the boxing ring. However, the absence of a union at the shop floor level indicates that even if they dance together they do it as individuals and not as a collective. This means that only parts of the regulatory arrangements that are related to participation and cooperation are implemented.

How the work is organized is important for employees' influence in the organization and for the regulation of working time. This is the issue in the next section.

\section{Working hours in a flexible organization}

The employees describe the organization structure as loose and refer to it as a fluid organization and they see it as lacking structure. This is because the work is very individualized and the employees feel that they lack the support that can be found in a more clearly structured hierarchy. It fits the criteria that have been used to describe a flexible organization of work (Kvande 2007; Skorstad and Ramsdal 2009). The work is projectorganized and staffed either by employees located in Norway and/or across national and continental borders, and each employee is individually responsible for completing the projects they are working on. Everybody has a card with an US-style job title showing the job they "really" have, but in actual fact they also carry out many other tasks. There is a great flexibility in the type of jobs they do. This gives the employees a great degree of autonomy in order to use their knowledge in both a creative and efficient way. James tells us that even if most of the projects are distributed by managers it is expected that each employee takes initiative: 
"This organization is a very young company, with lots of stuff that needs to be done, so that if you put up your hand and say that we should do something about this thing here, then you often get that project."

This way of organizing the work also means that the employees must be initiators: The realization of a good idea requires that individuals take initiative and follow up the project. Management encourages this and the employees feel that they have great freedom to design their own job. James continues his story:

"I constantly have three or four projects running, so that's what I have to work with. The rest, or other things than this, there's some chaos. Then tasks are flying at you from all over. You need a thick skin my boss told me when I started here. That really stuck in my mind, because the way it is, is that you have to be able to tolerate or have a little shield where things just bounce off. I have a plan, really, even if it's a bit vague, but roughly it's to become as skilled as possible in the field I'm working in, and as tough as possible. You won't become any better if you sit and hide all the time, so for me the idea is just to jump right in, daring to get roughed up a little."

He illustrates typical characteristics of flexible knowledge work; the empowered employee who was given good opportunities and much responsibility. The employees have good possibilities to influence their daily work situation, which is in line with the Working Environment Act $\$ 12$. At times it is chaotic and the advice from the manager, to be "tough and thick-skinned," means that he must shut out uncomfortable feelings and deal rationally with his work tasks. This has helped him focus on what is most important, becoming good, which requires risk taking and not always succeeding. Each employee is often involved in several projects and must also follow up ongoing and "flying" tasks that are initiated on the spot. According to Tom, management-inspired projects are especially exciting and demanding and can give status and have a career-enhancing effect.

"It's actually very exciting, because they have these incredibly strict requirements. So these are like the ulcer projects, for many. When you complete one of these, then I'd say this confers some status because it boosts your career."

Management-initiated projects are challenging and exciting. Here he describes them as "ulcer projects," which illustrates just how arduous they are. The employees understand that they are expected to spend considerably more time on them. In the worst case, work pressure can cause illness. Here we see that the individualized, empowered work organization also creates greedy time cultures (Børve and Kvande 2007), which requires employees to work very long hours, which exceeds to a very large extent the normal working hours in the Norwegian context.

Projects initiated by individuals require testing, which is very time-consuming. Thus, testing must be undertaken when the other tasks have been completed. Because these projects may contribute to technological innovation, this type of work makes that employee more visible in the company. This also leads to a system of "double shifts" in the company. On the "day shift," the employees work on projects initiated by the management and on the "evening or night shift," they work on their own projects to advance their own career. The company's philosophy is that employees should never say "No, 
that is not my task. You must rather say: What can I help you with?" It is about going that extra mile, in the words of Arne:

“This extra mile you have to go to move up and forward here. To make you visible, it's kind of important. I was given very much responsibility at once, and I like that. This makes you go that extra mile. I know that when the project I'm now managing gets really started, then I can really kiss my private life goodbye for the next few months."

The employee's talk about the heavy responsibility placed on each employee and how it makes them feel vulnerable. This illustrates the fact that the management's desire that employees go "that extra mile" has become a norm and part of the language used in the company. Arne goes that extra mile because it boosts his career and is necessary to follow up the work tasks for which he is responsible. He also says this is a strategy to meet requirements and thereby increase his own job security.

“Here we do our jobs and if we don't do a little extra there are plenty of people to take over your job. It is expected that you work hard. If I only had done what I was hired to do I had been fired."

It is assumed that the employees should work hard, understood as going that extra mile. The employees want to prove themselves as good and unique entrepreneurs, and for this, they increase their own job security. This implies that one must be available and put their time at the organization's disposal. Willingness to work is part of the construction of the dedicated employee. Time norms make it clear that each individual is responsible for delineating his or her own necessary working hours. Long working days express enthusiasm and dedication, and by living up to the requirements of the ideal employee, these employees contribute to the construction of a boundaryless time culture.

The organization's global operations require that employees in Norway and on other continents internalize the global clock (Kvande 2005). The global communication network makes time and distance lose their importance for when and where a person can be online. Projects across national boundaries and time zones contribute to making each employee feel responsible to be available for work 24/7, continuous “up-time.” In this way, the organization's global operations maintain the requirements for those who want to be seen as dedicated employees. This illustrates that availability is their symbolic capital.

The individual engineer and his/her knowledge constitute the company's capital or "gold," which is something some employees feel causes these people "to be treated like precious babies so they don't jeopardize their brain capacity." The employees must be available and willing to work as much as is possible for the company so that this capital can continually yield "outcome." To illustrate the "vulnerability" Harald told us a story that others also told us during the interviews:

"I have seen that they buy back the employee's holidays. When this happens many times, there are limits to how many times you can be bought, and you really start to ask what they are actually buying?"

The story he refers to concerns an employee who was holidaying abroad with his wife and children when a technological problem arose at the company that only he could 
solve. The outcome was that the father was forced to buy a laptop and spend several days working in the hotel lobby. This story illustrates the organization's dependency on individual cutting-edge competence. It also shows that not even holiday-time is decided upon by the individual. The technology supports this, as the work can be done anywhere in the world.

There seems to be no clear distinction between work and leisure time. Taking part in the working time culture that doesn't have distinct boundaries violates the institutional arrangement of the Norwegian regulation system. Carl believes that the time has come for other rules than, what he calls, the "buffalo law":

"The limit has been reached. We have been cowboys long enough. Cowboys who horse around and who're exploited for all they're worth. It's time the buffalo law is replaced by something else. The executioners are squeezing out everything there is, and then they're out of there. We're too vulnerable when the focus is on individual brains. It's time to think of the group instead of the individual."

The knowledge workers are dubbed cowboys, while the executioners are the managers, who according to Carl are practicing the "buffalo law" by trying to squeeze as much as possible out of the employees. Historically, this law refers to American Indians who hunted buffalo, culling the herd of weaker individuals to make the herd stronger. When the white men came, they butchered everything without a thought for the future, and they were only using a small part of the animal, the hide. One possible interpretation is that the buffalo law symbolizes how management has its focus on particular individuals and only exploits employee brainpower. The cowboys were also "entrepreneurs" in the sense that they conquered new land as they moved their flock of cattle. In this new country, no legal status had been established, lawlessness reigned, and every man made his own law. This is also a picture of the work organization in "our" company, where limits are fluctuating and it is up to each employee to determine what is right and what is not. It is up to the individual to decide how to do the job and how much they want to work. This is also an illustration of the situation in our company where there were few regulations and structures protecting and directing the employees.

When the employees were asked how many hours they work a week, they all stated that they work more than 40 hours a week. When we asked them to estimate the number of hours they worked, the majority stated that it was difficult to do so. This is partly due to the fact that they are online at home and check their mail but also that they are not necessarily in front of the screen for all their working hours. In addition, some were uncertain as to how many working hours a normal working week is, as Jon asked, "Is a normal working week 40 hours?" About employees who wish to work regular working hours he said, "I believe that kind of person could never be found here. Or rather, if they start, they would quit instantly. People who are here want to be here because it's exciting." He also tells us that the company has institutionalized the fact that they have applied to exceed the limitations of the Working Environment Act when it comes to overtime:

"We normally apply to exceed the limitations set by the Working Environment Act when it comes to working overtime. For us, dedicated employees are important. The concept of 
hours is relegated to the background. We are concerned with the entire person and make it quite clear that commitment is important. Being dedicated is an important characteristic for us."

A practice in applying to exceed the limitations of the Working Environment Act shows that there is a negation about the norms for working hours. The exceptions to the Working Environment Act time illustrate that the company challenges the institutional order.

The employees did not consider the Work Environment Act as a regulation that directly applied to their work situation. Richard told us that the management often claimed that the Norwegian working time regulations were not compatible with competing on the international market:

"There is a common accusation that circulates in top management that if we are to be a company in the top division of the world then we can't work within average Norwegian working time. Everybody has to work harder."

He also told us that the company has institutionalized the fact that they are allowed by the authorities to exceed the limitations of the Working Environment Act when it comes to overtime. This attitude toward Norwegian working time regulations seemed to be shared by the employees. Carl said the following about the company's international position and the Norwegian working time regulations:

"We are one of three biggest in the world in our field. Our competitors are all international companies. If we were to follow the law concerning working time regulations, in other words not letting people do their job, I can't imagine how it would have turned out. I think we would have just closed down the company."

This illustrates that many of the employees share this opinion and that this has become part of the culture in the organization. The Norwegian regulations in working life are considered counterproductive and therefore not to be followed. We asked how the different legal regulations in Norway were applied in the organization, especially those that regulate overtime. The answer was that they do not follow these regulations. Jonas told us the following story:

"Personally, I think it is strange that we do not follow the Work Environment Act and its regulations. We are a Norwegian company, but we do not have compensation for overtime, but we have flexibility. Maybe this is the reason, that if you can decide your own working time, you are not entitled to compensation time when you work. Maybe this is the way they can go around the Work Environment Act. I feel that at least those of us on the lowest level in the organization ought to have this type of protection. At this time, there is nothing being regulated because there are no data on how many hours we work. It is only when I decide to stop [working] that is the only factor that regulates it."

The absence of regulation of working hours implies that it is up to each individual to make a decision about working hours. You are on your own in this individualized organization. It is up to you to decide when you should stop working. This was the general opinion among the people with whom we spoke. 


\section{Discussion and conclusions}

In this article, we have analyzed the impact of internationalization as organizational processes where institutional actors meet in local contexts and negotiate the institutional order. Our point of departure has been how elements of the Nordic micro model are implemented in international professional organizations. We have focused on the institutional work that is done by employees and employers working in an international company with Norwegian founders that is situated in Norway. The internationalization of working life might imply that different traditions and practices meet and challenge each other (Børve 2010). In order to analyze how the institutional order in the Nordic model for working life is negotiated in concrete practices, our questions concerned two elements in the model. First, we have regarded the tradition of cooperation between employees and employers. In addition, we have focused on the organization of work in the company in order to analyze how the working time practice in the Nordic micro model is maintained.

The employees share an understanding that democracy and cooperation are norms that characterize the organization. Within Norwegian working life, these factors form the elements of the institutionalized understanding of participation rights in the Nordic model. The prevailing understanding is that most of the employees expect to be heard and to participate in the operations of the company. In general, it seems that employees and employers cooperate in line with this tradition in the Nordic micro model. In line with this the employees seem to have a democratic attitude - they speak their mind and are not concerned with hierarchical positions. The descriptions of Norwegian managers and their practices indicate that they exercise management in line with Scandinavian management traditions. Thus, important elements in the micro model are maintained.

There are, however, clear tensions between different institutional traditions in the organization. The managers who are from the United States appear to practice management in line with the liberal working life model (Westenholz 2011). The employees, who are mainly Norwegian, use the Nordic practices and rights based on laws and rules as a reference in their understanding of US management practices. Use of different control forms is seen as institutional work, which differs from practices where employees are given opportunities to influence and participate in organizational work. We can quite clearly find a tension-filled clash between these two different management practices. There is still a minority of the managers that are from the United States, but as we have shown in the analyses the international working life, where the United States is one of the leading nations, is put up as an example for Norwegian working life. This indicates that management in line with the Nordic micro model traditions might be under pressure. A very clear example of this is the manager's recommendation to employees not to become members of the trade union and the employee's adaption to this request. Employees' right to belong to a trade union is a crucial element in the Nordic micro model. This implies that employers and employees are not cooperating on a collective level. This means that only parts of the regulatory arrangements related to participation and cooperation are implemented.

Our second research question concerned working time in the organization and how it related to the institutional order represented by the Norwegian Work Environment Act and institutionalized working hour practices. This is a point where the institutional 
order of the Nordic micro model is really challenged and tensions are created. The company does not respect the regulations in the Work Environment Act and they see these regulations as counterproductive for a company that competes in the international market. There is a very clear devaluation of the regulations in the Nordic model. In addition we see that the individualized, empowered work organization also encourages a greedy time culture, which requires employees to work very long hours. This can also be observed in other knowledge organizations (Kvande 2009), but here it works together with the active devaluation of the institutional regulations that are found in the Nordic micro model, thus intensifying the effect of greedy organizations and challenging the institutional order represented in the model.

\section{References}

Alvesson, M. (1995) Management of knowledge-intensive companies. Berlin: Walter de Grunter.

Alvesson, M. (2004) Knowledge work and knowledge-intensive firms. Oxford: Oxford University Press.

Alvesson, M. and D. Kärreman (2004) 'Interfaces of control. Technocratic and Socio-ideological Control in a Global Management Consultancy Firm', Accounting, Organizations and Society, 29: 423-444.

Blair-Loy, M. (2003) Competing devotions: career and family among women executives. Cambridge, MA: Harvard University Press.

Børve, H. E. (2008) Norske kunnskapsorganisasjoner $i$ et globalt arbeidsliv (Norwegian knowledge organizations in a globalized working life). Phd thesis 2008: 319. Trondheim: Norwegian University of Science and Technology.

Børve, H. E. (2010) 'Ledelseskultur i en internasjonal, norskeid kunnskapsorganisasjon' (Management culture in an international, Norwegian owned knowledge organization), Nordisk Organisasjonsstudier, 1(12): 29-50.

Børve, H. E. and E. Kvande (2007) Tidskulturer i en global kunnskapsorganisasjon (Time cultures in a global knowledge organization), in E. Kvande and B. Rasmussen (eds.) Arbeidslivets klemmer (The work-life squeeze paradoxes in the new working life) (p. 107

125). Bergen: Fagbokforlaget.

Byrkjeflot, H. (1997) Institusjonelle forutsetninger for faglig ledelse og profesjonelle ledelseindustriledelse i tyskland og USA (Institutional prerequisites for management and professional management-industrial management in Germany and United States of America), in H. Byrkjeflot (ed.) Fra styring til ledelse (From leadership to management) (p. 85-122). Bergen: Fagbokforlaget.

Christensen, S. and A. Westenholz (eds.) (1999) Medarbeidervalgt i danske virksombeder fra lønarbejdere til borgere i virksombedssamfunet (Employee selected in Danish companies - form employment to citizens in the business community). Copenhagen: Copenhagen Business School Press.

Drucker, F. (1999) 'Knowledge worker productivity: The biggest challenge', California Management Review, 14(2): 79-94.

Epstein, C. F., C. Serron, B. Oglensky and R. Saute (1999) The part-time paradox. Time norms, professional lives, family and gender. New York, Routledge.

Esping-Andersen, G. (1990) The three worlds of welfare capitalism. Cambridge: Polity Press. Esping-Andersen, G. (1999) Social foundations of postindustrial economies. London: Sage. Esping-Andersen, G. and M. Regini (eds.) (2000) Why deregulate labour markets? Oxford: Oxford University Press. 
Fleming, D. and C. Thörnquist (2003) Nordic management-labour relations and internationalization - converging and divergent tendencies: A theoretical framework, in D. Fleming and C. Thörnquist (eds.) Nordic management-labour relations and internalization. Converging and tendencies (p. 9-22). Copenhagen: Nordic Council of Ministers.

Freeman, C. (2001) 'Is local: global as feminine: Masculine? Rethinking the gender of globalization', Signs, 26(4): 1007-1037.

Gooderham, P. N., O. Nordhaug and K. Ringdal (1999) 'Institutional and rational determinants of organizations practices: Human resource management in European forms', Administrative Science Quarterly, 44(3): 507-531.

Gooderham, P. N., O. Nordhaug and K. Ringdal (2006) 'National embeddedness calculative human resource management in US subsidiaries in Europe and Australia', Human Relations, 59(11): 1491-1513.

Heiret, J. (2003) International management strategies and models of industrial relations. A Norwegian experience, in D. Fleming and C. Thörnquist (eds.) Nordic management Labour relations and internalization. Converging and Diverging tendencies (p. 103-130). Copenhagen: Nordic Council of Ministers.

Hernes, G. (2008) Den norske mikromodellen. Virksomhetsstyring, partssamarbeid og sosial kapital (The Norwegian micro model. Business management, cooperation and social capital). Fafo notat: 25. Oslo: Fafo.

Hochschild, Arlie, R. (1997) The time bind. USA: Metropolitan Books.

Huzzard, T., D. Gregory and R. Scott (2004) Strategic unionism and partnership: boxing or dancing? Basingstoke: Palgrave Macmillan.

Kvande, E. (2005) Embodying male workers as fathers in flexible working life, in D. Morgan, B. Brandth and E. Kvande (eds.) Gender, body and work (p. 75-89). London: Ashgate.

Kvande, Elin (2007) Doing Gender in Flexible Organizations. Bergen: Fagbokforlaget.

Kvande, E. (2009) 'Work /life balance for fathers in globalized knowledge work. Some insights from the Norwegian context', Gender, Work and Organization, 16(1): 58-72.

Lawrence, T. B. and R. Suddaby (2006) Institutions and institutional work, in S. R. Clegg et al. (eds.) The Sage Handbook of organization studies (p. 215-254). London: Sage.

Lervik, J. E. B. (2005) Managing matters. Transferring organizational practices within multinational companies. Series of Dissertations 6/2005. Oslo: BI Norwegian School of management.

Løken, E., G. Falkenberg and T. Kvinge (2008) Norsk arbeidslivmodell - ikke for eksport? (Norwegian working life model - not for export?) Fafo-rapport: 32. Oslo: Fafo.

Morgan, G. (2001) The multinational firm: Organizing across institutional and national divides, in: G. Morgan, P. H. Kristensen and R. Whitley (eds.) The multinational firm: organizing across institutional and national divides (p. 7-23). Oxford: Oxford University Press.

Olsen, K. M. (2006) Jobbsikkerhet og nasjonale forskjeller (Job security and national differences.), in P. Heum, T. Nesheim, O. Nordheim and K. G. Salvanes (eds.) Arbeidsliv i omstilling (Restructuring in work life) (p. 109-123). Bergen: Fagbokforlaget.

Osmundsen, T. C. (2005) Becoming global - the troublesome integration process. Ph.d. avhandling. Trondheim: Norges teknisk-naturvitenskapelige universitet.

Powell, W. W and P. J. DiMaggio (eds.) The new institutionalism in organizational analysis. Chicago: The University of Chicago Press.

Ringdal, K., O. Nordhaug and P. N. Gooderham (2005) Amerikanisert personalledelse i norske bedrifter (Americanized management in Norwegian organizations), in H. Torp (ed.) Nytt arbeidsliv. Medvirkning, inkludering og belønning (New working life. Participation, inclusion and rewards) (p. 96-110). Oslo: Gyldendal akademiske.

Røvik, K. A. (2007) ‘Trender og Translasjoner' (Trends and translations). Oslo: Universitetsforlaget. 
Schramm-Nielsen, J., P. Lawrence and K. H. Sivesind (2004) Management in Scandinavia. Culture. Context and Change. Cheltenham: Edward Elgar Publishing.

Scott, W. R. (2008) Institutions and organizations. Ideas and interests. 3rd ed. California: Sage Publications.

Skorstad, E. (2007) Organisasjonsformer. Kontinuitet eller forandring? (Types of organizations. Continuity or change?). Oslo: Gyldendal Akademisk.

Skorstad, E. and H. Ramsdal (2009) Flexible organizations and the New Working Life. A European perspective. Farnham: Ashgate.

Strauss, A. L. and J. M. Corbin (1990) Basics of qualitative research. Grounded theory. Procedures and techniques. Newbury Park, CA: Sage Publication.

Trompenaars, F. (1993) Riding the waves of culture difference: Understanding cultural differences in business. London: Nocholas Brealey.

Trygstad, S. C. and I. M. Hagen (2007) Ledere i den norske modellen (Management in the Norwegian model). Fafo-rapport: 24. Oslo: Fafo.

Westenholz, A. (2003) Organizational citizens - Unionized wage Earners, participative management beyond, in B. Czarniawska and G. Sevon (eds.) The Northern Lights: Organization theory in Scandinavia (41-67). Malmø: Liber.

Westenholz, A. (2011) Is the Scandinavian way of organizing challenged by the growing Chinese economy? Paper to Nordic Sociological Conference, July, Oslo.

Yin, R. K. (1989): Case study research. Design and methods. Applied Social Research Methods Series, Vol. 5. London: Sage Publication. 